\title{
Indhold 2012
}

\section{Temaer}

Nordisk Tidsskrift for Kriminalvidenskab, 99. årgang Nr. 1: Fundamentals of Criminal Law

Nordisk Tidsskrift for Kriminalvidenskab, 99. årgang Nr. 2: Svenska Kriminalistföreningen 100-års jubilæum

Nordisk Tidsskrift for Kriminalvidenskab, 99. årgang Nr. 3:

\section{Regulering (Hovedredaktør Paul Larsson)}

Artikler

Alalehto, Tage: Regulering som policyfråga: En diskussion om regleringens effektier vid ekonomisk brottslighet

Anfinsen, Anne Marie, Linda Gröning, Jørn Jacobsen og Annika Suominen: Introduction

Asp, Petter: Denationaliserad straffrätt - vilka utmaningar står för dörren? .. 144

Christophersen, Jan Georg: Beredskap og kontroll av maritime transport .... 400

Fekjcer, Silje Bringsrud: Samme utdanning - ulik jobb? Spesialiseringspreferanser hos kvinnelige og mannlige politistudenter .....

Freivalds, Laila: Politikerna och kriminalpolitiken

Frisch, Wolfgang: Reflections on the Influence of Philosophy on Criminal Law Explaining Uniformity and Variety of Criminal Law in Europe ...... 3

Frände, Dan: »Rechtsgut « as a Finnish Concept - Some Observations ........ 19

Gröning, Linda: Towards a Theory of the Criminal Justice System ............. 27

Havelund, Jonas, Kristian Rasmussen \& Lise Joern: Eventbetjentuddannelsen - en forskningsbaseret uddannelse i dialogbaseret håndtering af masseforsamlinger

Hove, Kjersti: Kompetansebehov hos nytilsatt politi

Jacobsen, Jørn RT: Concepts of Criminal Law and Representative Reductions

Jung, Heike: »Justice must be seen to be done« ......................................... 65

Korsell, Lars: Ekonomisk brottslighet; tur och retur ................................... 293

Kyvsgaard, Britta: 100 års nordisk kriminalpolitik. Indlæg ved Svensk Kriminalistforenings 100-års jubilæum 
Lardén, Martin, Niklas Långström \& Martin Grann: Replik till Svartdal och Gundersen

Larsson, Paul: Regulering - en innledning

Larsson, Paul og Vanja Lundgren Sørli: Drosjenæring under lupen: kontrollpluralisme i praksis?

Ollus, Natalia og Anne Alvesalo-Kuusi: From cherry-picking to control: migrant labour and its exploitation in finnish government policies ......... 376

Roth, Venla: Osynliga offer: Identifiering av människohandel som hänför sig til sexuellt utnyttjande

Svartdal, Frode \& Knut Gundersen: Virker ART i svenske fengsler?

Träskman, Per Ole: Organiserad brottslighet, ekonomisk brottslighet och terrorism - hänger de samman?

Tiilikka, Päivi: Avvägningen mellan yttrandefriheten och skyddet för privatliv i emd:s praxis - lotteri eller enhetlig verksamhet?

Victor, Dag: Från behandlingsideologi till nyklassicism

von Hofer, Hanns: Det svenska fängtalets utveckling 1910-2010

Wandall, Rasmus H.: Styring af straffastsærrelsen med domsbaser - Anklagemyndighedens Vidensbase

\section{Boganmeldelser}

Garde, Peter af ANDREAS LAURSEN: Internationale forbrydelser i dansk ret

Greve, Vagn af HENRIK SKOV KRISTENSEN: Straffelejren. Fårhus, landssvigerne og retsopgøret

\section{DIVERSE}

Henrik Tham: Digt

Indhold 2012

Årsberetning 